\title{
"Collateral Damage in the War on Travel Writing": Recovering Reader Responses to Contemporary Travel Writing
}

\begin{abstract}
Scholarship of travel writing has seldom paid proper attention to questions of how and why readers engage with the genre - an oversight which, as Robin Jarvis (2016) has noted, at times leads to negative generalizations about travel writing's presumed audience. This article examines this issue, and considers ways of recovering actual reader responses - through surveys of online reviews, and qualitative interviews. The article outlines findings from a structured group discussion with six regular readers of travel writing. Particular attention is paid to the way these readers respond to the possible inclusion of fictional elements in notionally non-fictional travel books, with the discussion revealing a broad conservatism on this point, and a general rejection of fictionalisation as a travel writing practice. This finding is contrasted with ideas voiced during the author's interviews with notable travel writing practitioners, revealing a significant tension between the production and reception of the genre.
\end{abstract}

Keywords: travel writing, reader reception, audience, fictionalization, travellee, Paul Theroux

\section{Introduction: The Reader in Travel Writing Studies}

The scholarship on travel writing has often concerned itself with the questions of how the travel writer encounters and then represents what Mary Louise Pratt (2008) calls the travellee - that is, those people in the places that the traveller passes through, or perhaps over. Indeed, travel writing scholars at times appear to be interceding on behalf of the travellee. The dynamic arranged around 
a travel text, then, might be said to consist of the travel writer looking at the travellee, and the travel writing scholar looking at the travel writer looking at the travellee.

Something, obviously, is missing here, for as Michael Harbsmeier notes, when viewed as a social fact, "any travel account involves at least three parties: the traveller himself, his audience, and the people encountered, observed and described" (221; emphasis added). There has been a certain amount of recent scholarship focused on readers' responses to historical travel writing - through examination of correspondence, reviews, marginalia, and so on. But curiously, as Robin Jarvis has recently pointed out, how and why the seemingly more accessible audience of contemporary travel writing might actually engage with texts "are not questions that travel writing studies has so far considered worthy of serious investigation" (89).

To be sure, the existence of readers is routinely acknowledged, as, for example, in Jan Borm's extremely useful definition of travel writing itself as:

[A]ny narrative characterized by a non-fiction dominant that relates (almost always) in the first person a journey or journeys that the reader supposes to have taken place in reality while assuming or presupposing that author, narrator and principal character are but one and the same.

(17; emphasis added)

But the reader here remains a wraithlike, abstract figure. The existence of actual readers with actual agency is obscured. And when travel writing scholarship debates "ways of reading travel writing" (Youngs 163), it is typically seeking to suggest critical approaches, rather than "how to read travel writing" as a "common reader," or even as a literary critic operating outside of a strictly academic framework.

\subsection{Guilty by Association: The Reader in Critiques of Travel Writing}

Before going any further, it is necessary to ask whether the absence of attention to readers really matters. I would argue that it does, if for no other reason than that travel writing scholarship often seeks to ask questions concerning the genre as a whole, rather than single, sealed texts. It 
considers travel writing as "a total social fact," as Harbsmeier has it (221), and audience is clearly an important component of this social fact. The success or otherwise of a particular travel book (or grouping of books) within the genre - namely how popular it proves with readers - does have a direct impact on what subsequently gets published, and therefore what gets commissioned, and ultimately even where and how a travel writer travels, who he or she encounters and represents. Readers, then, may have a direct impact on the direction of the genre - which, sad to say, is probably less often true of travel writing scholars. Travel writers are likely to be to some degree aware of readers' responses to their texts, and may modify their practice accordingly - though certain tensions do emerge here, as will be shown later. Readers obviously matter.

A failure to consider the concrete detail of readerly experience is also an issue when it comes to scholarship - and there has been a good deal of it - carried out in what Carl Thompson calls "a pronounced spirit of critique, and indeed censure, rather than celebration" (4). Here, it seems, readers are sometimes deemed guilty by association, complicit in travel writing's alleged crimes. Robin Jarvis cites what he calls the "sweeping generalizations" (89) of Holland and Huggan about travel writers pandering skilfully to the whims of a readership with "complacent, even nostalgically retrograde, middle-class values" (viii). Further examples can be found in the work of the arch scholarly antagonist of contemporary travel writing, Debbie Lisle. Discussing a typically caustic passage set on the US-Mexico border in Paul Theroux's The Old Patagonian Express (1979), she states that:

Theroux's judgement of the garlic seller resonates with readers because it calls upon many other shared interpretations of the unequal relationships between Mexico and America (e.g. developed and underdeveloped, civilised and primitive, First World and Third World). Suddenly, the heavy security presence at the US border begins to make sense to Theroux's readers - America needs to be protected from those hordes of filthy characters symbolised by the garlic seller. By augmenting the Mexican-American border with descriptions of cultural difference inherited from a colonial past,

Theroux invites his readers to sanction the structures of power that justify America's most militarised and violent national border. (Lisle 7)

This passage creates an effective simulacra of dynamic readerly agency - albeit with a single, uniform response set. We seem to observe readers finding that the text "resonates"; we observe 
their moment of realization as a certain political reality "begins to make sense" and receives their sanction. But of course, these are pseudo-observations; actual readers do not ever get to confirm whether the text resonates with them at all. This is an example of what Jonathan Rose calls the receptive fallacy, where "the critic assumes that whatever the author puts into a text - or whatever the critic chooses to read into that text - is the message the common reader receives" (49). Here, and in Holland and Huggan's work, as Robin Jarvis somewhat provocatively puts it, actual readers have "become collateral damage in the war on travel writing" (89).

\section{Online Reviews and Contemporary "Travellee Polemics"}

So what to do about this? Jarvis has suggested that neither reception theory, nor reader-response theory, get us properly to actual reader reactions. Instead, he argues, "there is an urgent need for empirical studies" (92). The internet is an instantly accessible starting point. There are countless blogs and reader forums, and the hundreds of reviews posted to the Amazon and Goodreads websites offer a largely untapped resource for at very least an instant, ad hoc gauge of reader responses to a given travel text (Jarvis himself conducts a brief, experimental foray into the use of Amazon reviews as a research resource). Even a cursory glance at these websites reveals that while there will almost always be some readers who find that a particular travel book does indeed "resonate," others will absolutely hate it. This fact alone is enough to problematize the monolithic "complacent, even nostalgically retrograde" readership (Holland and Huggan viii) assumed in the critiques mentioned above.

We might, for example, make a brief survey of the more negative Amazon reviews of Paul Theroux's The Happy Isles of Oceania. (1992), a travelogue describing a journey through parts of Australia, New Zealand, various Pacific Ocean states and Hawaii. This is a book for which Lisle reserves a particular animosity (xi), and it soon becomes apparent that there are plenty of readers who share her perspective.

On the British Amazon site, a [Customer] notes that:

According to Theroux, every Pacific island is inhabited by a lazy, mendacious, tardy, thieving and lying populace devoid of culture and manners. Fellow travellers to these islands do not escape the 
wrath of Theroux's pen as they are collectively dismissed as fat, ignorant, oafish and rude. Yet for all his criticisms of other people for being rude, racist, indifferent and obdurate, the clear impression from reading the book is that Theroux is the worst offender of the lot ... Sadly, my lasting impression was not one of beautiful sandy beaches, blue lagoons or vibrant coral reefs, but of a sad and bitter old man who would do well to paddle to a deserted island and not return.

Another reviewer, draws unfavorable comparisons with Tobias Smollett, demonstrating an interesting awareness of the historical canon (Daplyn). Over on the US Amazon site, [Amazon Customer] observes that Theroux "expresses near-hatred of Japanese for coming to the Pacific and 'taking over' ... but forgets that Euros/Americans have been doing the same thing for hundreds of years."

There's plenty of entertainment to be had here, but perhaps the most significant of these hostile reader responses are such as that from Paddle, who states that:

As an Australian and a good friend of several Pacific Islanders, I was quite offended by this book. Theroux makes sweeping generalizations about Australians, New Zealanders, and Pacific Islanders that are derogatory and border on racism.

Another review, from Brenda Friedrich, begins with the same three words - "As an Australian" and expresses similar sentiments. Likewise, Jamie Surman finds his or her negative response to the book colored by "having grown up in Oceania." And Hawaii resident DCite is "embarrassed that I had to share Oahu" with Paul Theroux.

These reviews, despite similarly critiquing the text itself, and often on similar grounds, in fact challenge the assumptions made about travel writing's readers in some of the more censorious scholarly accounts. These scholarly assumptions at times suggest, perhaps inadvertently, a curiously binary view of a world divided into places travel writers come from - which are also places where travel writers' readers live - and places where travel writers go, inhabited by mute travellees, seemingly incapable of receiving the travel writers' texts. But the Amazon reviews of The Happy Isles of Oceania from Australians and Pacific Islanders cause this binary conception to fragment, and also reveal the existence of what Wendy Bracewell has called "the travellee-reader" (216) - the literate travellee, fully capable of receiving a traveler's text. And as Bracewell's work on 
the eighteenth-century "travellee polemics" - written responses to (typically) negative travel accounts of the travellees' home place - has revealed, travellee-readers have been around for a long time. The hostile Amazon reviews which make a point of foregrounding the reviewers' own position in the places the reviewed writer describes can be regarded as contemporary travellee polemics.

Returning briefly to another Theroux book, The Old Patagonia Express, Debbie Lisle's discussion of a presumed audience response to its depiction of the US-Mexico border clearly takes no account of the likelihood that some part of that audience will have read from south of that border, either in the English-language original, or in the later Spanish translation, El viejo expreso de la Patagonia (2001). Lisle's depiction of a single, uniform audience response, with the text "resonating" because of assumptions shared with the writer, makes no allowance for the response - in all probability radically different to that which she describes - of these travellee-readers.

\section{Letting the Reader Speak: Discussing Travel Writing with the Globetrotters Club}

Clearly online reviews have their limitations as an area for empirical research. It is impossible to judge how representative they are of broader reader responses; the contexts of each review cannot be assessed; and their authors cannot be further interrogated. To open up such possibilities, it is necessary to take a lead from the more exemplary travel writers - and actually to talk to people.

\subsection{Methodology}

With this in mind, in early 2018 I set up a round-table discussion with a small group of travel writing readers. To be clear, this was a preliminary foray, intended simply to gauge how valuable such an exercise might be, and thus I sought an easily identifiable group of people likely to be regular readers of travel writing. I found such a group in the membership of the Globetrotters Club. This London-based organization describes itself as "the travel club for independent travellers \& travel enthusiasts of all ages" ("Welcome"). It hosts monthly meetings at the Church of Scotland in 
Covent Garden, where guest speakers and club members give presentations on their journeys. At the February 2018 meeting I introduced my research and asked for volunteers. I then sent these volunteers a brief online survey to complete and invited some of them to take part in a live discussion ahead of the Globetrotters meeting the following month. In the event, six readers took part.

It is important to stress that the group was self-selecting, drawn from a discrete community, and that as actual as well as armchair travelers, their reading of travel writing may not be particularly representative of a wider readership. Conversely, they are largely London-based, and all possess sufficient disposable income to indulge their own interest in world travel. Here, we might expect to find the archetype of a "complacent, even nostalgically retrograde, middle-class" audience (Holland and Huggan viii). However, it is worth pointing out that the group was equally split along gender lines; two members unprompted by me, made reference to their "working class" backgrounds during the course of the discussion; and one described herself as a working class woman of color. Even what might seem to be travel writing's core demographic may turn out to be more diverse than expected when encountered in the flesh.

For the exercise I used a semi-structured, qualitative interview technique, in line with the approach I have used when interviewing travel writing practitioners elsewhere. The clear difference here was that there were six interviewees, rather than a single informant, which necessitated an initially somewhat more structured approach: a series of predetermined questions were presented to the group. After each question was posed the discussion was allowed to develop between participants, with follow-up questions posed by the interviewer as they arose. The discussion lasted a little over an hour; an audio recording was made, and a written transcript was later completed.

\subsection{Snapshots of Readers' Responses to Travel Writing}

The most significant finding to emerge from the exercise relates to the readers' reactions to the possible inclusion of fictional elements in notionally non-fictional travel writing - responses which I will here briefly contrast with statements from several travel writing practitioners I have interviewed. To begin, however, I will provide snapshots of other interesting, and perhaps significant, points raised during the discussion. 
In response to a question about why members of the group read travel books, David, a retired sales manager in his seventies, says:

Well, I think by definition being Globetrotters we're already nailing our colors to the mast and this is the icing on the cake - [we read travel books] either to confirm what we thought about a place, or to discover about a place. ${ }^{[1]}$

Here the possibly problematic distinction of this group is underscored: their reading is likely to be directly connected to their own travelling, which may not necessarily be the case for the majority of readers of travel writing. (This question in itself would be a particularly interesting area for more extensive research: to what extent is regular consumption of travel writing determined by a predilection for actual travel, and then to what extent might the personal experience of a particular place determine the choice of specific texts?) However, in response to David, Gavin, a selfemployed photographer in his forties, says that:

Sometimes I don't want to read books before I go.

Sandra, a tour organizer for a UK coach company, in her seventies, agrees:

Normally I read a book after I've been to a place, not before.

Zillah, a lawyer and company secretary in her fifties, responds directly to this:

l'd agree with that. Slightly coming back to Gavin's point about not wanting to frame or prejudge before you go to a place, but having come back from a place and then perhaps seeing what other people have written or perhaps filling in some more color about the place or a bit more of the history.

Adam, a former schoolteacher and now a PhD candidate in his fifties, also agrees:

Sometimes you don't want to make a judgment about a place ... for me sometimes because l'm curious I do like to find out about what's beneath the surface and I find some travel books - not all 
- help you with that. But they can push you in a direction that is actually wrong, and you might be looking at certain things, and that's not actually what's happening.

Edward Said describes the way that travelers encountering new places tend to "fall back on a text" - to defer to the antecedent authority of books, very much including travel writing, because "people, places, and experiences can always be described by a book, so much so that the book (or text) acquires a greater authority, and use, even than the actuality it describes" (93). But here a group of traveling readers are describing actively resisting that process, revealing an innate awareness of the very problem Said describes. Of course, it would be naïve to suggest that simply by avoiding reading a travel book about Sri Lanka before going to Sri Lanka, as in Adam's case, he has dodged the influence of established discourses about the place. But these comments do suggest that readers are less inclined simply to receive a text passively, unaware of its potency, than some scholarly critiques might suggest.

Another interesting snapshot: Adam describes how he has made several journeys to Sardinia where he has actively tried to follow in the footsteps of D.H. Lawrence. Scholarly discussions of the "in the footsteps of" mode of travel writing itself typically stress its depending "heavily on the discourse of nostalgia" (Lisle 223) and its heightened sense of belatedness (Youngs 89). And by allowing Lawrence's book, Sea and Sardinia (1921), to shape his own journey, Adam is very definitely falling back on a text. However, he seems to be neither motivated nor subsequently affected by belatedness or nostalgia:

So we met some people there who were interested that we were interested and it meant that we met other people in the country. I mean, found out loads about unemployment, about politics, about what's going on with jobs and people, being invited to people's houses because of this book.

A particularly fascinating snapshot is the stark commentary on a book by Dervla Murphy ${ }^{2]}$ from Roslyn, a business performance manager in her fifties who is, it is important to say, a woman of color from, by her own account, a working class background:

I was so disappointed, because I thought as someone who's an established traveler and she's travelled to these places. But the way she was describing her encounters with the locals I just 
found deeply disappointing. I mean obviously it's very Eurocentric, she can't be anything other. But I thought perhaps there might be something, that she could have that objective view. But it was the same sort of Eurocentric view that she brought to bear on the local people ... You know, typically it's the warm friendly locals - "oh, they were warm and friendly and welcoming!" And I just found that so patronizing and offensive. Because I think most Europeans travel with that expectation. I mean any program that you watch on TV, any book that you read written from a Eurocentric perspective is about the warm friendly locals and the expectation that they're going to be friendly, they're going to welcome you into their homes, they're going to provide for you and blah blah blah.

And I just find that deeply problematic, that they can't sort of move beyond that and have a relationship, a one-to-one relationship - you know, a human being relating to a human being without all that sort of baggage and that expectation.

What is significant here is that Roslyn's pronouncedly negative response further problematizes the idea of a uniform audience response - and a uniform "resonation" of the text with its readers - as implied in some of the critical scholarship discussed above.

Various other ideas emerge in the discussion, including a general preference for books that do not dwell on an "inner journey," and a general dislike of books featuring a heroic authorial persona, though as Sandra interjects, "Levison Wood - you've got to excuse him because he's so damn good-looking; you just sit and look at the cover."

\subsection{Reader Responses to Fictionalization in Travel Writing}

Finally, I want to look at the readers' discussion of one particular issue in a little more detail, that of the introduction of fictional elements into notionally non-fictional travel books.

Despite the fact that most scholarly attempts to define travel writing, such as that from Jan Borm quoted above, stress its non-fiction status, many scholars seem relatively relaxed about the "element of fictionality" (Korte 180) in travel books. Indeed some, such as Corinne Fowler and Claire Lindsey, have commented favorably on the possibility of deploying fictional elements to promote "affective identification" with the travellee (Lindsey 99).

Initially, in discussing the possibility of travel writers adding elements of fictionalization to their 
work, the Globetrotters Club readers appear to be thoroughly pragmatic, and markedly open-eyed about the writing process.

Adam says:

Was it Bruce Chatwin who wrote about Patagonia [In Patagonia, 1977] and there was a big controversy about it? Well, I remember reading that book and I really liked it, and then when this controversy came out I didn't really follow it very closely, but I thought is that going to change my idea about the book? No it's not actually because it's a book. And so I know a lot of people got very excited about it. So to me to a certain extent I would go with it, because that's the writer's interpretation, of what they've seen and the story that they're trying to portray.

Roslyn comments: "I'm just wondering how much they can actually remember, for an entire book. Is all of it going to be factual? I can't see how that's possible," to which Sandra responds, "I agree. I think you have to paint a picture sometimes, so somebody feels that they're on the bus with you." Zillah then says:

And one of the days might have been raining all day and they might sort of take the morning of one day and the afternoon three days later and put it together, and well actually it doesn't matter because the sun's come out in the afternoon in their book, when in fact it rained all week. That doesn't matter.

But what is striking is that the tone changes immediately when I introduce specific hypothetical examples of fictionalization which may occur in a travel book. The entire group agrees that the sort of condensing of timescales that Zillah has described is acceptable. However, only half of the group feel that reordering actual events in the narrative would be acceptable. David, one of those who wouldn't accept this practice, says:

It's a representation of the facts; that you'd be caught out in that particular lie, clearly you're not someone who can really be trusted to tell the whole truth.

No one in the group would find moving a travellee to a different location from that in which they were actually encountered acceptable: 
Zillah: Well, culturally they might be different.

Roslyn: Tribally they might be different.

Gavin: In fiction l'd be happy for that; you can make up your character and put them wherever you want. But if you're believing in non-fiction, then no.

Similarly no one in the group finds the idea of creating composite characters acceptable. Adam argues, to general agreement around the table, that:

I think if you were writing a fictional book that would be fine, but not a travel book. I think that's not respecting people's individuality and character. I think that actually that's - well, not just patronizing; I think that's poor practice to do that, actually.

The group are similarly unwilling to accept the obscuring of the presence of travel companions, guides, practical arrangements, other tourists, and of self-fictionalization in terms of the "inner journey." And when it comes to the insertion of outright fictional elements - events, individuals, and experiences that did not actually exist in any form - the negative response is unanimous, as voiced by Gavin:

\section{That's fiction!}

So the group's initial apparent tolerant pragmatism has given way to a pronounced conservatism on the issue of fictionalization in travel writing. The discussion would probably make uncomfortable listening for many travel writing practitioners, even those who regard themselves as broadly "reliable."

\section{Conclusion: Tensions between the Conventions}

Briefly to consider what may actually be going on here, it seems likely that when it comes to travel texts, what Siegfried J. Schmidt terms the aesthetic convention, which allows readers to suspend disbelief when reading fiction, remains firmly subordinate to the "fact convention" governing 
reception of news reports, everyday conversations, and so on. The liminal space - or perhaps contact zone - between the fact and aesthetic conventions may arguably offer ethical possibilities likely to meet the approval of scholars such as Fowler and Lindsey. But judging by the responses of the Globetrotters Club readers to examples of fictionalization in travel writing, it seems to be dangerous territory for travel writers in terms of the response of the general audience.

Many practitioners appear to recognize this. Rory MacLean discusses his practice of inserting fantastical elements as rhetorical signals to indicate the unstable nature of a text (in terms of a fiction/non-fiction binary): "I'm saying 'fictional elements here, boys and girls, be aware!' So I do change location, I do change the sex of some of the people; I do have composite characters." (MacLean)

However, Philip Marsden is probably more typical in his discussion of what he calls a "contract with readers" (Marsden) - a contract to produce non-fiction, that is - and the problem of even minor violations of that contract prompted by, for example, the need to disguise an informant's identity and location.

A certain tension is dimly revealed here, particularly when the idea that the appearance of truth and the appeal therein to the "fact convention" - is not necessarily the same thing as the truth, a truth, or truth of any kind whatsoever. As Mary Baine Campbell writes of the notoriously unreliable John Mandeville, he must be received as truth "because he sounds like truth" (127). Sara Wheeler, another notable contemporary travel writer, expresses this:

I feel that l'm creating a work of literature, so the demands of making it an acceptable work override, in my opinion, any question of verisimilitude ... I'm trying to write a book that's going to grip people from start to finish and I believe I'm allowed to do whatever I like - to do whatever I like

- to be faithful to my material, to be faithful to the truth. Often the truth is truer than the truth, in other words, "He didn't say that, then, did he?" No, but there's a truth that's truer than the truth, and I believe that it's my right as a writer to create that work.

But when asked how readers might respond if they become aware of this assumed imperative, she states: "They hate it, and they say, 'I'm never going to read a word you write ever again!' So I should keep my mouth shut." (Wheeler) 
This key tension between the production and the reception of travel writing - a tension seemingly confirmed by the opinions of the readers of the Globetrotters Club - may be another area worthy of further investigation. Such an investigation would, of course, rely on continuing to develop empirical research that allows readers of travel writing to speak, to have readerly agency. As Robin Jarvis states, "The only alternative, it seems, is to fall back on the derogatory generalizations that have so far passed for critical analysis of travel readers" (97).

\section{Works Cited}

[Amazon Customer]. "Kayaking Oceania with Archie Bunker." Amazon, 15 July 2001, www.amazon.com/gp/customerreviews/R236Z54Y78ANVX/ref=cm_cr_arp_d_rvw_ttl?ie=UTF8\&ASIN=061865898X. Accessed 28 Oct. 2018.

Borm, Jan. "Defining Travel: On the Travel Book, Travel Writing and Terminology." Perspectives on Travel Writing, edited by Glenn Hooper and Tim Youngs, Ashgate, 2004, pp. 13-26.

Bracewell, Wendy. “The Travellees' Eye: Reading European Travel Writing, 1750 -1850.” New Directions in Travel Writing Studies, eds. Paul Smethurst and Julia Kuehn, Palgrave Macmillan, 2015, pp. 215-27.

Campbell, Mary B. The Witness and the Other World. Cornell University Press, 1988.

Chatwin, Bruce. In Patagonia. Jonathan Cape, 1977.

[Customer]. "A Travel Novel about the Author and Not the Destinations." Amazon, 1999, www.amazon.co.uk/gp/customerreviews/R1V08417Y874QE/ref=cm_cr_arp_d_rvw_ttl?ie=UTF8\&ASIN=0140159762. Accessed 28 Oct. 2018

Daplyn, Mike. “A Dismal Whinge.” Amazon, 27 Apr. 2006, www.amazon.co.uk/gp/customerreviews/R2BSLEXXTG4HK3/ref=cm_cr_arp_d_rvw_ttl?ie=UTF8\&ASIN=0140159762. Accessed 28 Oct. 2018 
DCite. "Irritating, Racist, Filled with Bias, Ignorant \& Uninformed." Amazon, 30 Apr. 2005, www.amazon.com/gp/customerreviews/R3EZMA7BJB3LGF/ref=cm_cr_getr_d_rvw_tt|?ie=UTF8\&ASIN=061865898X. Accessed 28 Oct. 2018.

Fowler, Corinne. "Fiction and Affect: Anglophone Travel Writing and the Case of Paraguay." Travel and Ethics: Theory and Practice, edited by Corinne Fowler, Charles Forsdick, and Ludmilla Kostova, Routledge, pp. 52-76.

Friedrich, Brenda. "Theroux's Unhappy, Brief Journey to Australia." Amazon, 17 Feb. 2016, www.amazon.com/gp/customerreviews/RDMW28JWTE3X0/ref=cm_cr_arp_d_rvw_ttl?ie=UTF8\&ASIN=061865898X. Accessed 28 Oct. 2018

Harbsmeier, Michael. "Spontaneous Ethnographies: Towards a Social History of Travellers' Tales." Studies in Travel Writing, vol. 1, no. 1, 1997, pp. 216-38.

Holland, Patrick, and Graham Huggan. Tourists with Typewriters: Critical Reflections on Contemporary Travel Writing. University of Michigan Press, 1998.

Jarvis, Robin. "Travel Writing: Reception and Readership." The Routledge Companion to Travel Writing, edited by Carl Thompson, Routledge, 2016, pp. 89-98.

Korte, Barbara. English Travel Writing: From Pilgrimages to Postcolonial Explorations. Macmillan Press, 2000.

Lindsey, Claire. Contemporary Travel Writing of Latin America. Routledge, 2010.

Lisle, Debbie. The Global Politics of Contemporary Travel Writing. Cambridge University Press, 2006.

MacLean, Rory. Personal interview. 2 Oct. 2017.

Marsden, Philip. Personal interview. 20 Apr. 2015.

Paddle, C. "Paddling Theroux's Bias." Amazon, 1 Sept. 20014, www.amazon.com/gp/customerreviews/R2O1R1YC7VNC34/ref=cm_cr_getr_d_rvw_ttl?ie=UTF8\&ASIN=061865898X. Accessed 28 Oct. 2018. 
Pratt, Mary Louise. Imperial Eyes: Travel Writing and Transculturation. 2nd ed., Routledge, 2008.

Rose, Jonathan. "Rereading the English Common Reader: A Preface to the History of Audiences." Journal of the History of Ideas, no. 53, 1992, pp. 47-70.

Said, Edward. Orientalism. Pantheon, 1978.

Schmidt, Siegfried J. Foundations for the Empirical Study of Literature: The Components of a Basic Theory. Buske, 1982.

Surman, Jamie. "Smug." Amazon, 10 Jan. 2002, www.amazon.com/gp/customerreviews/R3U1IPLNYBV1S4/ref=cm_cr_getr_d_rvw_ttl?ie=UTF8\&ASIN=061865898X. Accessed 28 Oct. 2018.

Theroux, Paul. The Old Patagonian Express. Houghton Mifflin, 1979.

Theroux, Paul. The Happy Isles of Oceania. Putnam, 1992.

Theroux, Paul. El viejo expreso de la Patagonia. Ediciones B, 2001.

Thompson, Carl. Travel Writing. Routledge, 2011.

"Welcome to the Globetrotters Club." The Globetrotters Club, globetrotters.co.uk/. Accessed 28 Oct. 2018.

Wheeler, Sara. Personal interview. 4 Dec. 2017.

Youngs, Tim. The Cambridge Introduction to Travel Writing. Cambridge University Press, 2013. 
[1] This and all subsequent quotes from readers are from the group interview conducted by the author on March 3, 2018.

[2] The Waiting Land (1967); Where the Indus is Young (1977).

\section{c) (i) (9)}

Creative Commons Attribution-NonCommercial-NoDerivatives 4.0 International License 